\title{
KIT wt Allele
}

National Cancer Institute

\section{Source}

National Cancer Institute. KIT wt Allele. NCI Thesaurus. Code C51741.

Human KIT wild-type allele is located within $4 q 11-q 12$ and is approximately $83 \mathrm{~kb}$ in length. This allele, which encodes mast/stem cell growth factor receptor protein, plays a role in the mediation of transmembrane-receptor interactions. Mutations in the gene are associated with gastrointestinal stromal tumors, mast cell disease, acute myelogenous leukemia, and piebaldism. 